\title{
STRATEGY FOR INCREASING FARMERS' INCOME THROUGH DRY LAND RESOURCES COMBINATION IN KUPANG DISTRICT OF NUSA TENGGARA TIMUR
}

\author{
Keban Arnoldus*, Lalus Matheos F., Sogen Johanes G. \\ Faculty of Animal Science, University of Nusa Cendana Kupang, Indonesia \\ *E-mail: info@undana.ac.id
}

\begin{abstract}
Dryland farming is an activity carried out traditionally by farmers on using various resources such as the type of livestock that is kept, land for rainfed rice fields and fields. Types of plants include food crops in the form of rice and corn, vegetables, horticulture, and also labor and capital. All these resources are cultivated in combination even though they have not been allocated optimally, but this is an inseparable part of their habits, so that if an optimum model of resource allocation is found, farmers will certainly apply it to obtain maximum income. What is the combination of each resource that can generate maximum income for farmers; this is the main problem of this research. Research result; the resources owned by farmers are allocated optimally which results in maximum income, if the paddy field area is 0.58 hectares; land area for $0.64 \mathrm{Ha}$ corn, land for planting cassava covering an area of 4.39 $\mathrm{Ha}$ and for vegetables $0.06 \mathrm{Ha}$ per family; raising cattle as much as $1.18 \mathrm{AU}$; pigs $0.80 \mathrm{AU}$ and raising goats $0.33 \mathrm{AU}$. The optimum allocation of all resources owned by the farmer mentioned above generates income of IDR 35,249,269.12. Cattle play a payment tool for customary fines in the marriage of Atoni Meto, and as dowry.
\end{abstract}

\section{KEY WORDS}

Allocation, optimization, revenue maximization, social and cultural roles.

Climate conditions in the East Nusa Tenggara (NTT) region, consisting of a relatively long dry season (8-9) months and a relatively short rainy season (3-4) months. Thus farming in this area is dominated by dry land farming with a traditional business system. The livestock business carried out by farmers is also still traditional, which is done by releasing cattle to find their own food in public grazing fields during the day and being caged at night. This will have implications for increasing food production which runs relatively slowly (Abdurahman, Dariah and Mulyani, 2008)

There are 3 ways of raising cattle in Kupang NTT Regency, namely: a) an extensive method, namely all cattle are released to find their own food during the day and sometimes guarded by a shepherd; b) fixed tie method, where all cattle needs depend on the owner, feeding is done by cut and carry, and c) how to maintain a combination of ways a) and b) (Lalus, 2018). Meanwhile, in food crop farming, more than the types of crops, namely corn, beans, and yams are cultivated in the same area without optimum combination planning; therefore this research becomes important to do (Abdurachman, Dariah and Mulyani, (2008).

In conducting cattle business, farmers use various resources they have. It is almost certain that the allocation of these resources has not been done optimally so that the income of farmers is not maximum, because of the extensive traditional maintenance system (Awang, Ariana and Siryani, 2016). This is the main reason for the need for this research, the consideration is, although the allocation of various resources owned by farmers is not yet optimum, it is an integral part of the lives of farmers, so that an optimum resource allocation system is found. The main objective of farmers to maintain several types of livestock is as a buffer stock or buffer risk; intended not for daily consumption needs, but for socio-cultural needs such as marriage ceremonies, death and repairing or building new homes.

The important thing in an effort to improve the standard of living of farmers is through improving their farming by summarizing various alternatives in various business branches in an agricultural production process. Increasing production in the agricultural sector means finding the right way to use various resources owned; among others, the allocation of 
resources owned by farmers such as land allocation: forage for livestock which includes grass and other forages, corn, rice, beans (horticulture), yams and others. Allocation of capital and labor in financing all plant production activities and types of cattle raised. How much is the allocation of each resource that can generate maximum income for farmers is the main reason for this research.

Research purposes:

- To analyze the combination of various resources owned by dryland farmers in Kupang NTT Regency;

- To assessing the role of cattle from socio-cultural aspects and economic aspects in the perspective of the community in Kupang NTT Regency.

The allocation of various resources owned and cultivated by farmers includes farming of fields and fields (rainfed and irrigation) of food crops such as maize, beans, yams and livestock business consisting of cattle, pigs, goats and chicken livestock. This combination of food crops is not done on different business areas, but is done on the same land that is not separated. This is what makes it difficult to measure production per unit area of business land. Similarly, the maintenance system for various types of livestock is still traditional.

\section{METHODS OF RESEARCH}

This research was conducted in Kupang NTT Regency, with concentrations in Taebenu District and Kupang Tengah Subdistrict, in 2018. In general, farmers in this area are not monoculture, but try to mix several species of livestock and try some types of plants in the same area.

Sample determination is done in two stages (two stage sampling). The first stage of the determination of two sample sub-districts, namely Taebenu and Kupang Tengah Districts, was purposive by considering having the most cattle population and also farmers working on food crops in a combination (Nazir, 2014; Singarimbun and Effendi, 2011, Silalahi, 2010). With the same consideration, two sample villages were chosen from each sub-district as follows: Oeltua Village and North Baumata Village in Taebenu District; Oelnasi village and Noelbaki village for Central Kupang areas. The second stage, the determination of respondents was also conducted purposively by considering the number and types of livestock kept, as well as various types of food crops and horticulture that were cultivated. The number of respondents for each village is as follows: Oeltua (16 respondents) and North Baumata (24 respondents); Oelnasi (20 respondents) and Noelbaki (18 respondents); the total number of respondents is 78 households.

Data collection was carried out by direct interview techniques with sample farmers based on a prepared list of questions. Data collected includes primary data and secondary data. Primary data include: the number and type of livestock kept, ownership status, length of maintenance, land area allocated for each type of plant cultivated, production per unit of cultivated land area and others. While secondary data includes, selling price per unit (both livestock and plants), all data / information needed in this study, collected from respondents through direct interview techniques using a questionnaire.

The main approach used to analyze this research data is the Linear Programming approach through the Simplex Algorithm for maximizing income from the allocation of the use of various resources owned by farmers, as instructed by Aritonang R. (2016); Nasendi and Anwar (1995); Nesa Wu and Richard Coppins (1981). The importance of this analysis is intended to find out that the use of resources owned by farmers has been allocated optimally? The problem of resource allocation in traditional farmers' livestock raising must be formulated in advance into the general problem of linear programming as follows:

$$
\begin{gathered}
Z_{\max }=c_{1} X_{1}+c_{2} X_{2}+\ldots+c_{j} X_{j}+\ldots+c_{n} X_{n} \\
a_{11} X_{1}+a_{12} X_{1}+\ldots+a_{1 j} X_{j}+\ldots+a_{1 n} X_{n} \leq b_{1} \\
a_{21} X_{1}+a_{22} X_{1}+\ldots+a_{2 j} X_{j}+\ldots+a_{2 n} X_{n} \leq b_{2} \\
a_{i 1} X_{1}+a_{i 2} X_{1}+\ldots+a_{i j} X_{j}+\ldots+a_{i n} X_{n} \leq b_{i} \\
A_{m 1} X_{1}+a_{m 2} X_{1}+\ldots+a_{m j} X_{j}+\ldots+a_{m n} X_{n} \leq b_{m} \\
X j \geq 0 \text { for } j=1,2, \ldots, n
\end{gathered}
$$


Where: $\mathrm{Cj}=$ Parameters used as optimization criteria or decision-making variable coefficients in the objective function; $\mathrm{Xj}=$ Change in decision making or activity you want to find, which is unknown; aij = technology efficiency / decision-making variable (related activities) in the i-th constraint; bi = Limited resources, which limit the activity or business concerned from the $i$ th constraint; $Z$ = Scalar value for decision-making criteria for an objective function.

\section{RESULTS AND DISCUSSION}

The dominant farming in Kupang Regency is farm farming. The cultivation of fields in research locations in general has adopted a system of permanent farming and is familiar with fertilization and pest eradication technology. Schmitt 1991, Chavas 2001, Summer and Wolf 2002; cited by Bowman and Zilberman (2013) that, in the 20th century brought significant changes to the global agricultural economy. Meanwhile, farming operations are generally still owned by farmer families, and farm size, management and production methods as a whole are more advanced in mechanization and specialization compared to before.

A quite encouraging development is that, farmers in the sample locations have applied technology without tillage. As many as $78.21 \%$ of farmers have fertilized, $75.59 \%$ have carried out prevention and eradication of plant pests. For paddy fields (both irrigated and rainfed rice fields) $97.44 \%$ of farmers fertilize and $96.15 \%$ do pest control. Even some farmers whose entire production has been commercial in nature means that most or almost all of their produce is intended for the market.

The results showed that of all sample farmers $97.44 \%$ of them had used fertilizers and $96.15 \%$ used pesticides and weed drugs, both for rice fields and gardens or fields. The results of the interview indicated that, one part of the land preparation effort before planting was spraying the grass, because before the farmers planted, the grass had grown, so it was sprayed so as not to interfere with plant growth. This, according to the farmers, will save labor, especially in weeding. According to Rahim and Dwi Hastuti (2008) that the actual use of fertilizers in a farm is likened to a human being, in addition to consuming staple food nutrients, it is also necessary to consume vitamin nutrients as an additional staple food. Likewise with plants, besides water as its main consumption, fertilizer is needed in optimal growth and development. The type of fertilizer used by farmers is organic fertilizer and inorganic fertilizer. Organic fertilizers include; manure, green manure and compost; while inorganic fertilizers include urea, TSP and KCL and Ponska.

Of all respondents interviewed, $75.76 \%$ of them used fertilizer. There is an interesting phenomenon, namely, the use of fertilizers by farmers is mostly done in the dry season in "corn water" which is an area planted with corn and beans and drained from the nearest water source that can reach the land, at least once a week. While gardens planted with corn by farmers during the rainy season, $78,21 \%$ of them do fertilization.

The average area for land owned by farmers in the study location was $0.64 \mathrm{Ha}$, for rainfed rice fields it was $0.58 \mathrm{Ha}$. This land has been cultivated by $98.76 \%$, and $94.12 \%$ has been planted. Of the total area which had been planted $92.42 \%$ of the produce and harvested by farmers, the remaining $7.58 \%$ did not produce. This is caused by many factors, among others, lack of rainfall or after planting rain no longer falls for quite a long time, so that sometimes farmers have to replant when it rains again or even late planting or being attacked by pests.

The labor force used in farming activities in the fields / gardens consists of human labor originating from within the farmer's family and from outside the family. The total amount of labor available to a farmer is generally used to work in the fields (both irrigation and rainfed) as much as $52.08 \%$ and $47.92 \%$ work in fields or gardens. The availability of labor as intended for various activities such as plowing, planting - weeding, and harvesting. According to Priyanti, Sinaga Syaukat and Kuntjoro (2008) that the use of labor in the family is allocated to rice farming, cattle business, non-integration farming, while the outpouring of labor as laborers on farms owned by other people and business workers outside agriculture. The demand for labor outside the family is carried out for rice farming and non-integration 
farming. The use of this family workforce is distinguished according to male, female and child laborers by calculating the number of hours in a year.

According to Parson, cited by Hermen Malik (2015), the characteristics of rural communities with social and cultural systems are as follows: 1) affinity, relation to feelings of affection, love, loyalty and intimacy. Its form is the nature of helping help among the people; 2) collective orientation, increasing togetherness, disliking self-assertiveness; 3) particularism, all things related to what is specific to a particular place or area and 4) description, relating to quality and special characteristics. Such characteristics of society will have an effect on the farming that is carried out, especially in concocting various resources owned in such a way as to obtain maximum income.

Today, farming in the fields or gardens of the farmers is much helped by the availability of various weed killers or grasses at affordable prices. From the interviews, it was found that, $75.64 \%$ of the total respondents had used grass spraying drugs and $78.21 \%$ had used fertilizer. As for rice fields, $97.44 \%$ of farmers have used fertilizers and $96.15 \%$ use drugs to protect pests and grasses. As a consequence of the use of fertilizers and medicines for spraying pests and grasses, the cash outlays by farmers are as follows: the average cost for purchasing fertilizers is IDR $766,121.79$, and for the purchase of pesticides and grasses, the average is IDR $333,846.15$ for each planting season.

The non-cash costs incurred to pay labor in field farming are 8.01\% (IDR 56,690.14) originating from within the family while $91.99 \%$ (IDR 600,202.56) comes from outside the farmer's family. The use of labor from outside the family is mutual cooperation, (the local term "Hokatofa") is generally in the activities of weeding and planting.

In this "hokatofa" activity, it is the landowners who bear the consumption during the activity. This means that cash or non-cash expenses occur. Cash expenditure is intended to buy side dishes and rice. The results of this study indicate that cash expenditures in weeding and or planting activities averaged IDR 707,371.79. It is realized that the value of this amount of money is too small for the present. Of the total respondents interviewed, it turned out that only $9.09 \%$ of respondents carried out activities like this.

If the activities mentioned above do not involve labor from outside the family, then the time needed especially for weeding activities can reach 2-4 weeks (on average 3 weeks), if the activity is carried out continuously every day. The reason is, the time needed during that time is, if in the land preparation activities and not sprayed first on the grass that grows before planting activities are carried out.

These workers (especially those involved in planting activities) also returned to use during the corn harvest. Where each worker gets an average salary of IDR359,015.- or equivalent to 2.69 real maize, where 1 (one) real is equal to 400 grains of corn. So if the labor wage is as high as above, if it is converted into the amount of corn which is as many as 1,077 grains.

While labor is involved in paddy fields, namely in the activities of planting, weeding and harvesting. Workers for planting activities are generally paid for with rice. For 1 (one) hectare are $(\mathrm{Ha})$ rice fields are paid for by rice as much as 30 blik (local size), where 1 rice paddy if converted in kilograms as much as $15 \mathrm{~kg}$ or $7-10 \mathrm{~kg}$ of rice. So if 30 pieces are converted in $\mathrm{kg}$, meaning that every ha of paddy fields, farmers must spend an average of $240 \mathrm{~kg}$ of rice as labor costs. The amount of wages if converted again into rupiah, means that in one planting season the farmer must spend as much as IDR 1,200,000 - as labor wages. Whereas if the labor costs are paid in cash, then the salary is only IDR 500,000 - IDR $1,000,000$ per ha or an average of IDR750,000 per ha. The same labor is used again during harvest activities, and is paid with rice as much as 1 (one) rice paddy per day. For example the amount of labor used at the time of harvest of 5 people, then at the time of harvest, every day the owner of the rice field must issue rice as a labor wage of 5 months. In addition to the wages of labor as mentioned above, farmers also pay cash fees for tractor rental on average per hectare of IDR586,730.77.

Most of the respondent farmers (61.54\%) prepared corn seeds they bought from the store, and the remaining $38.46 \%$ used corn seeds which were prepared themselves at harvest time. The number of seedlings prepared by the farmer from the yield, on average 1 
(one) "real" is equal to 400 grains of corn, which if converted into units of kilograms will be equivalent to $50 \mathrm{~kg}$ (average 8 grains $=1 \mathrm{~kg}$ ). When asked, why prepare as many seeds as that? The reason is just in case because old stored corn is usually partly damaged by eating moth (a type of louse) or with the local term "fufuk". Whereas by buying from a store, the average cash expenditure that must be made by farmers is IDR 167,175.32.

Production and use of production results from Farming and Livestock Businesses. The discussion about the use of corn production in this study is not expressed in physical units, but is directly converted into the value of money (rupiah). The allotment of corn production by farmers in the research location is to consume farmers with their families, sell it to the market, and pay for labor and supply seeds. In general, the production of "corn water" is mostly aimed at the market; this is mainly done by farmers in two research villages, namely villages: Oeltua and North Baumata (100\%). As for respondents in the village of Oelnasi, from all farmers the respondents stated that they did not work during the dry season while the respondent farmers in the village of Noelbaki cultivated or planted corn in the dry season by $22,22 \%$.

Contribution of food crops (including beans) to income (cash $6.70 \%$ and non-cash $12.75 \%$ ) household or overall contribution of food crops farming is $16.03 \%$. Livestock business contributes $24.66 \%$ for cash income and $57.41 \%$ for non-cash income of dryland farmers in the study area, and overall the contribution of livestock business is $66.70 \%$. Whereas the contribution of other sources to farmers' income is $1.71 \%$.

In general, livestock ownership (especially cattle) is self-owned (96.32\%) while the remaining $3.67 \%$ maintains or maintains livestock belonging to other people with a profit sharing system. The revenue sharing system encountered at this research site is that the profit sharing system is as follows, $70 \%$ of the difference between selling price and buying price for fattening farmers and $30 \%$ for livestock owners. So, if a calf is purchased at a price of IDR 3 million, after being fattened for approximately 6 months, then sold at a price of IDR 6 million, then the livestock owner gets IDR 1,900,000, while IDR 2,100,000 for the farmers who are fattening.

The average ownership of $4.32 \mathrm{AU}$ cattle, 1.31 pigs, $0.07 \mathrm{AU}$ goats and chicken 0.09 AU. Whereas if fattening, then the division is like in cattle. For chicken livestock, it does not occur as in the two types mentioned above, because in general the chickens that are kept are free-range chicken and in very limited quantities. So that if an outbreak occurs, all chickens will die, because farmers in this location almost never vaccinate. Of all respondents, only $27.27 \%$ vaccinated chickens raised, including $4.54 \%$ of broiler breeders.

The motive of farmers in raising livestock is as a source of income (economic motives), as savings that can be cashed at any time if the need for cash is for an urgent need, consumption and socio-cultural interests. The results of interviews with respondent farmers, almost never found a single motivated farmer in raising livestock. Except for broiler breeders (purebred chicken) solely aimed at the market. Extensive maintenance systems are characterized by: 1) farmer farmers have not been market oriented (market oriented), 2) health care has not been properly considered, 3) livestock regeneration has not received adequate attention and 4) production cannot keep up with increasing demand, both in the form of live animals and in the form of meat (Lalus, 2007). Schiere, Ibrahim and van Keulen (2002) state that in the sustainability of livestock raising systems, there are a number of specific objectives as follows: 1) livestock play an important role in the sustainability system of the existence of farming systems, especially mixed food crops and livestock farming, 2) classification of livestock business systems, including differences in livestock production and mixed farming, in access to land, labor and capital.

In terms of socio-cultural interests, especially cattle and pigs have an important role in traditional ceremonies such as marriage, death. According to Hidajat (1976), cattle act as a payment tool for custom fines in the marriage of Atoni (timor people), for example in a love relationship between a young man and a young woman, it turns out the young woman is pregnant before marriage, and if the young man refuses to marry the girl, then the young man is fined a sarong and a cow and a pig. The use of the word Atoni Meto by Hidajat (1976) is actually inappropriate, because the word "Atoni" itself in the context means people. So 
actually what was meant by Hidajat was "Atoni Meto" (literal translation was land people) or commonly translated as Timorese.

For example, in the engagement, if later the young man does not want to continue the engagement to the marriage level, then the young man is fined a cow to cancel the engagement and at the same time give the girl the freedom to marry someone else. While the fine on "eloping" is 7 (seven) cows, a silver bracelet and a blanket. It was also explained that, according to the Atoni people, to build a new house not by selling rice or corn or beans but selling cattle. It is easy to understand that if cattle are valued with money then it has a much greater value than the production of food crops and horticulture in the same calculation unit. In Atoni Meto weddings in Kupang Regency, beef and pork are a must. Almost never found a marriage party Atoni Meto without the two types of meat mentioned above. It is very coincidence that $87.18 \%$ of the respondents in this study were Timorese, so for that reason the discussion on the socio-cultural side as above was on the Timorese tribe. Another important role of cattle in Atoni Meto culture is as "belis" (dowry). From an economic standpoint, the contribution of livestock business to farmers' income is $59.75 \%$. From the magnitude of this donation, cattle gave the largest contribution of $75.35 \%$, pig livestock $20.81 \%$, goat livestock $1.90 \%$ and chicken $1.98 \%$.

In essence all activities on family farming cannot be separated from one another, but must be seen as a whole. Thus in discussing the combination of branches of food crop farming and livestock business, it must also be seen as a single unit.

The results of Masbulan's research (1999) show that the research was conducted to obtain a conceptual basis for the development of agricultural business systems in the critical area of Yogyakarta, as the smallest producer unit, specifically to: (1) obtain an optimal dairy cow-based farming system and obtain maximum income with resources available to farmers and with capital assistance from funders, (2) obtain a model for developing a dairy cowbased farming business system in the critical land area of the Special Region of Yogyakarta.

The method used is a stepwise problem solving approach in the agricultural business system in Glagaharjo Village, Cangkringan District, Sleman, which begins with a diagnostic survey through "Rapid Rural Appraisal (RRA) and Agro-ecosystem Analysis" activities. Next, a farm record keeping and survey is held by interviewing 40 respondents purposively. By choosing a linear planning model (MPL) a riormative problem solution is produced, namely problem solving that will produce maximum benefits within the constraints of each business activity to measure the effectiveness of the development of a dairy cow-based agricultural business system. The results showed that the management of land resources had not been carried out optimally, from the average ownership of 1.5 ha of legal land to only 0.6 ha that was processed, so that the appearance of the level of agricultural business yields and farmers' income was relatively low. The optimal implementation of a dairy cow-based farming business system is an alternative improvement area. By including the role of the dairy farming cooperative as a business driver (Model Scenario I), it can increase farmers' income. Of the 1.5 ha of dry land cultivated and the maintenance of dairy cows a maximum of 3 Livestock Units (AU) at optimal conditions, the income reaches IDR 20,385,340, - during the production period of 8 years. The amount of income can be increased by applying Scenario II Model, which is the inclusion of venture capital with a soft interest rate of up to IDR $36,176,070$, - for 8 years, other benefits obtained, namely land resources and family labor are used optimally, increasing the scale of business of dairy cows to 4 ST, and if developed to 1,400 farmers according to plan, it will be able to absorb as much labor as 230 people (year 1), which tends to increase until the eighth year reaches 1,154 people / year. In the end it can be concluded that the development of a dairy cow-based agricultural business system can strengthen the economic resilience of families in critical land areas and can gain land conservation development programs.

The results of the input-output analysis indicate that the total average net income of each business branch is as follows: for paddy rice (X1) of IDR 5,745,000.00; corn (X2) of IDR $2,850,555.56$; legumes (X3) of IDR 1,029,516.67; and cassava (X4) of IDR 538,350.00. For livestock business includes cattle (X5) of IDR 9,638,811.00; pig livestock (X6) in the amount 
of IDR 3,561,428.57; goat livestock (X7) of IDR 1.011.111,11; and chicken (X8) of IDR $1,113,000.00$.

The limiting factors or constraints that are considered in this study are the average land area: 0.65 ha of rice for the type of rice plant; $0.62 \mathrm{Ha}$ for corn, for legumes is 0.12 ha and for cassava plants is 1.31 ha. Cattle as much as $4.58 \mathrm{AU}$; $0.17 \mathrm{AU}$ goat cattle; $0.80 \mathrm{AU}$ pigs and $0.13 \mathrm{AU}$ chickens AU. The amount of labor and capital available for the various activities above are 1242.55 HKP and Rp. 13,043,918.91.

The mathematical model for a combination of food crop farming and livestock business is formulated as follows:

\section{$\operatorname{Max}(Z)=5.745 .000 X 1+2.850 .555,56 X 2+1.029 .516,67 X 3+538.350 X 4+9.638 .811 X 5+3.561 .428,57 X 6+1.011 .111,11 X 7+1.113 .000,00 X 8$}

Constraints functions:

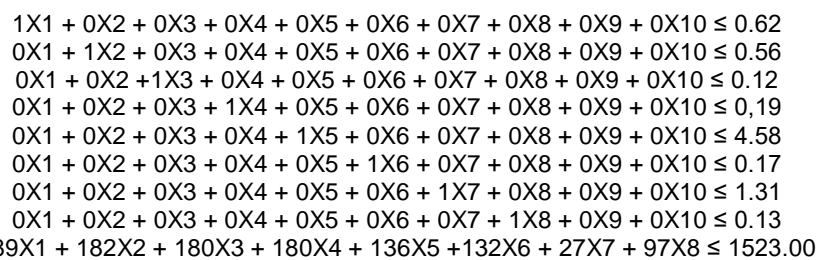

$696676,47 X 1+478966,47 \times 2+414166,67 X 3+623316,67 X 4+4899583,26 \times 5+3929285,71 \times 6+1035361,11 \times 7+409800 \times 8 \leq 13.043 .918,91$

Table 1 - Production Factors Using per Unit Activities on Food Crops Farms and Animal Farm in Kupang Regency

\begin{tabular}{|c|c|c|c|c|c|c|c|c|c|}
\hline Production factors & Available & $\mathrm{X} 1$ & $\mathrm{X} 2$ & $\mathrm{X} 3$ & $\mathrm{X} 4$ & $\mathrm{X} 5$ & $\mathrm{X} 6$ & $\mathrm{X} 7$ & $\mathrm{X} 8$ \\
\hline $\begin{array}{l}\text { Land }(\mathrm{Ha}): \\
\text { Paddy } \\
\text { Corn } \\
\text { Horticulture } \\
\text { Ubi2an }\end{array}$ & $\begin{array}{l}0.62 \\
0.56 \\
0.12 \\
0.19 \\
\end{array}$ & $\begin{array}{l}1 \\
0 \\
0 \\
0 \\
\end{array}$ & $\begin{array}{l}0 \\
1 \\
0 \\
0\end{array}$ & $\begin{array}{l}0 \\
0 \\
1 \\
0 \\
\end{array}$ & $\begin{array}{l}0 \\
0 \\
0 \\
1\end{array}$ & $\begin{array}{l}0 \\
0 \\
0 \\
0 \\
\end{array}$ & $\begin{array}{l}0 \\
0 \\
0 \\
0\end{array}$ & $\begin{array}{l}0 \\
0 \\
0 \\
0\end{array}$ & $\begin{array}{l}0 \\
0 \\
0 \\
0\end{array}$ \\
\hline $\begin{array}{l}\text { Livestock (AU) } \\
\text { Cow } \\
\text { Goat } \\
\text { Pig } \\
\text { Chicken }\end{array}$ & $\begin{array}{l}4.58 \\
0.17 \\
1.31 \\
0.13\end{array}$ & $\begin{array}{l}0 \\
0 \\
0 \\
0\end{array}$ & $\begin{array}{l}0 \\
0 \\
0 \\
0\end{array}$ & $\begin{array}{l}0 \\
0 \\
0 \\
0\end{array}$ & $\begin{array}{l}0 \\
0 \\
0 \\
0\end{array}$ & $\begin{array}{l}1 \\
0 \\
0 \\
0\end{array}$ & $\begin{array}{l}0 \\
1 \\
0 \\
0\end{array}$ & $\begin{array}{l}0 \\
0 \\
1 \\
0\end{array}$ & $\begin{array}{l}0 \\
0 \\
0 \\
1\end{array}$ \\
\hline Labour (DWM) & 1523.00 & 589.00 & 182.00 & 180.00 & 180.00 & 136.00 & 132.00 & 27.00 & 97.00 \\
\hline Capital (IDR) & $13.043 .918,91$ & 696676,47 & 478966,47 & 414166,67 & 623316,67 & 4899583,26 & 3929285,71 & 1035361,11 & 409800 \\
\hline
\end{tabular}

To get the optimum combination of programmed resources, as a first step is to enter the slack variable so that a basic program is feasible (Iteration I in the Table). In this feasible basic program (Iteration I), farmers have not carried out activities so that the income earned is zero. The combination of resources owned by farmers as presented in the table above, through the Simplex Algorithm, farmers' profits can be increased little by little.

In iteration II, the farmer decided to only raise $4.58 \mathrm{AU}$ cattle with an income level of IDR 25,660,930.26. - with reduced cost (marginal value product=MVP) of IDR 9,638,811, - It turns out that at this stage, the activity of planting rice in rainfed rice fields, planting corn, beans, sweet potatoes, raising livestock for pigs, goats and chickens, can still be implemented. This condition can be seen in the Zj-Cj line (opportunity cost) which is still negative. This implies that if all of the above activities are carried out in the amount of one unit each, it will increase farmers' income as much as the value of each of these activities. Therefore, this program is a feasible basic program, but it is not an optimum program, because there are still activities that are still negative, so it can still be continued to the next iteration.

The next program (iteration III), the farmer decided to increase the activity of processing and selling rice production on a rice field farm covering an area of $0.62 \mathrm{Ha}$. The farmer's decision to add to this activity caused his income to increase to IDR 28,373,088.13. At this stage, rice farming activities have a shadow price of IDR4,374,448.17, which means that if the farmer decides to add another unit of paddy activities or to plant rice, then an additional income of that value will be obtained. It seems that up to this stage, management 
of maize, yams, raising goats, cattle and chickens as well as farming activities as shown in the $\mathrm{Zj}-\mathrm{Cj}$ line is still worth less than zero or negative.

Based on the description in the third iteration above, this program is still continued to iteration IV, which includes the activity of planting corn on an area of 0.56 ha. It turned out that the farmers' decision to include the activity of planting corn caused an increase in their overall total income to IDR $29,441,735.02$. This program is also a basic program that is feasible but not optimal, because the values of other activities on the $\mathrm{Zj}$-Cj line are still negative. So that it can still be forwarded to the next iteration (iteration $\mathrm{V}$ ).

Until the $V$ iteration, the combination has not reached its optimum because there is still a negative value, which means that farmers' income can still be increased if farmers decide to add activities to grow yams, raise goats, pigs and other activities other than farming such as masons, wood and so on. This is indicated by the values on the $\mathrm{Zj}$-Cj line which are still negative.

In the $\mathrm{V}$ iteration, the decision taken by farmers is to grow vegetables in a garden area of an average of $0.12 \mathrm{Ha}$ per family. As a result of this decision, farmers' income increased again to IDR 29,503,853.23 This VI iteration is a sound basic program, but it is not an optimal program, because there is still a negative $\mathrm{Zj}-\mathrm{Cj}$ value. Thus, business combination activities can still be continued to $\mathrm{VI}$ iteration.

In $\mathrm{VI}$ iteration, farmers decided to add 1.31 AU (Animal Units) per family to raise pigs because this activity had a Reduced cost (MPV) of IDR 1,113,000.00, which means that the income will increase by that value if they carry out raising goats. With the additional activities of raising goats, farmers' income increased to IDR 29,529,621.83. This VI iteration is an iteration where the optimum combination of various business branches or production factors owned by farmers. It is said to be the optimum combination because all the values in the $\mathrm{Zj}$ Cj line are no longer negative.

Optimization of farmer income in Kupang Regency as indicated by the linear programming approach through the simplex algorithm above that the income of dryland farmers in the area includes land allocated for the overall dryland farming activities covering an average area of $0.12 \mathrm{Ha}$ per household; cattle 4.58 AU; $0.17 \mathrm{ST}$ goat cattle; $1.31 \mathrm{AU}$ pig and 0.09 AU chicken with income of IDR 29,529,621.83.

\section{CONCLUSION}

The types of plants used by breeders in Kupang Regency include: rice, corn, beans consisting of peanuts, long beans and rice beans; sweet potatoes include: cassava (cassava) and yams. While the types of livestock kept include: cattle, pigs, goats and chicken livestock.

The optimum combination that produces maximum income for farmers in Kupang Regency is IDR $35,249,269.12$. This happens if the cultivated land area is 0.59 hectares; land for planting corn covering an area of $0.62 \mathrm{Ha}$; for cassava with an area of 0.52 hectares and for beans covering an area of 0.45 hectares. While the types of livestock include livestock: cows 4.58AU; 1.31 AU pigs, 0.17AU goat and 0.10AU chicken.

Contribution of food crops (including beans) to income (cash and non-cash) of farmer households is $29.30 \%$ and $19.20 \%$ or overall the contribution of food crops is $22.11 \%$. Livestock business contributes $70.70 \%$ for cash income and $80.80 \%$ for non-cash income of dryland farmers in the study area, and overall the contribution of livestock business is $77.89 \%$. Whereas those from other sources contributed to farmers' income of $1.40 \%$.

Contributions from rice, corn and horticulture farming (long beans and peanuts) to cash income of $12.27 \% ; 11.52 \% ; 1.12 \% ; 0.96 \%$. The contribution of rice and corn to farmers' noncash income is $12.45 \%$ and $6.18 \%$; Long beans do not have a contribution to non-cash income, because this type of plant is the main purpose of its business for the market, meaning that all of its products are for sale. There were no leftover products intended for seedlings for the following planting season, because the seeds for the next planting season were purchased from the store. Peanut contribution to non-cash income is $0.44 \%$. 
Contributions from each kind of livestock are as follows. Cattle provide the largest contribution to cash income of $39.13 \%$ and non-cash income of $49.80 \%$ compared to other types of farming. Pigs are the second largest contributor to $26.70 \%$ in cash income and $25.27 \%$ in non-cash income. The contribution of goats and chickens to cash income is $1.69 \%$ and $2.80 \%$ respectively, while non-cash income is $1.13 \%$ and $0.30 \%$ respectively.

\section{REFERENCES}

1. Abdurahman, A; A. Dariah and A. Mulyani, 2008. Strategy and Technology of Dry Land Processing Supporting National Food Procurement. Center for Research and Development of Agricultural Land Resources. Jl. Ir. Juanda No. 98 Bogor 16123. Journal of Agricultural Research 27 (2), 2008.

2. Aritonang R, Lerbin R. 2016. Operations Research. Publisher in Media Jakarta.

3. Antara, Made and Nyoman Suardika (2012). Resource Allocation Optimization in Dryland Farming Systems in Kerta Village, Gianyar, Bali: Linear Programming Approach. Journal of Applied Quantity Economics.

4. Awang, A. K., I N. T. Ariana and N. L. P. Sriyani, 2016. Dimensions of the Body of Balinese Cattle Cared for at the Suwung Denpasar Final Waster Place and Bali Cattle Breeding Center in Sobangan. E-Journal. Tropical Animal Husbandry. Udayana University. Journal of Animal Science. Vol. 4 No. 2 of 2016: 393 - 404.

5. Bowman, M.S. and D. Zilberman, 2013. Economic Factors Affecting Diversified farming Systems. Ecology and Society 18 (1): 33. Department of Agricultural and Resource Economics, University of California, Berkeley.

6. Budiasa, I Wayan; I G A. A. Ambarawati, I Made Mega; I Ketut Mangku Budiasa, 2012. Optimization of Integrated Farming Systems to Maximize Farmer Income. E-Journal of Agribusiness and Agro Tourism. ISSN: 2301-6523 Vol.1 No.2 October 2012.

7. Hermen Malik, 2015. Build the Village Industry Save the Nation. IPB Press publisher.

8. Hidajat Z. M, 1976. Society and Culture of Ethnic Groups in East Nusa Tenggara. Tarsito Publisher Bandung.

9. Lalus, Matheos F. 2007. Study of Farming Display in Dryland Poor Farmers in Kupang Regency, East Nusa Tenggara. Research Report. Faculty of Animal Husbandry, Nusa Cendana University.

10. Lalus, Matheos F. 2018. Analysis of Integration of Beef Cattle Markets in Kupang Regency, East Nusa Tenggara. Dissertation. Postgraduate Program of the Faculty of Animal Science, Brawijaya University, Malang.

11. Nasendi, B.D. and Affendi Anwar, 1985. Linear and Variation Programs. PT Gramedia Jakarta Publisher.

12. Nedi, Benedict; Suprapti Supardi, and Joko Sutrisno, 2013. Analysis of Corn Farming in Grobogan Regency, Central Java Province. Agribusiness Review Journal. Volume1 No. 1 (December 2013), pp. 33-44 ISSN. 2354-8320

13. Nesa Wu; Richard Coppins, 1981. Linear Programming and Extensions. McGRAW-HILL Company.

14. Masbulan, 1999. Optimization of Dairy Business Systems (Soup) Based on Dairy Cattle in the Critical Land of the Special Region of Yogyakarta. JITV. Vol 4. No. 4 of 1999.

15. Priyanti, Atien; Bonar M. Sinaga; Yusman Syaukat and Sri Utami Kuntjoro, 2008. Impact of the Plant-Animal Integration System Program on Farmer Income and Expenditures: Household Economic Simulation Analysis. Postgraduate Forum Vol.31 No. January 1, 2008; 45-58.

16. Rahim, Abd., Diah Retno Dwi Hastuti, 2008. Agricultural Economics (Introduction, Theory and Case). Agriwawasan Series. Penebar Swadaya Publisher, Jakarta

17. Schiere, J.B, M.N.M.Ibrahim and H. van Keulen, 2002. The Role of Livestock for Sustainability in Mixed Farming: Criteria and Scenario Studies under Varying Resource Allocation. Agriculture Ecosystem \& Environment 92 (2002) 139-153.

18. Silalahi, Ulber, 2010. Social Research Methods. Refika Aditama Bandung Publisher.

19. Singarimbun, M; Sofyan Effendi, 2011. Survey Research Method. LP3ES Jakarta. 